Research Article

\title{
Students' opinions on the prevailing and innovative methods in medical education technology and changes recommended
}

\author{
Misal Devika D. ${ }^{1}$, Maulingkar Saleel V. ${ }^{2}{ }^{2}$, Meural A. D’Mello ${ }^{3}$, Rataboli P. V. ${ }^{3}$
}

\author{
${ }^{1}$ Department of Pharmacology, \\ DMWIMS Medical College, \\ Meppadi, Wayanad, Kerala, \\ 673577, India, \\ ${ }^{2}$ Department of Microbiology, \\ DMWIMS Medical College, \\ Meppadi, Wayanad, Kerala, \\ 673577, India, \\ ${ }^{3}$ Department of Pharmacology, \\ Goa Medical College, Bambolim, \\ 403201, Goa, India
}

Received: 01 November 2015 Accepted: 18 December 2015

\section{*Correspondence to: \\ Dr. Maulingkar Saleel V., Email: saleelmaulingkar @yahoo.com}

Copyright: ( $)$ the author(s), publisher and licensee Medip Academy. This is an open-access article distributed under the terms of the Creative Commons Attribution Non-Commercial License, which permits unrestricted noncommercial use, distribution, and reproduction in any medium, provided the original work is properly cited.

\begin{abstract}
Background: Medical education technology has evolved greatly and it is essential to keep abreast of the recent techniques to keep the students focussed in the classroom. It is also necessary to receive feedback and input from the students regarding our teaching methodologies. Our aim was to learn from the learners about their opinion regarding the current teaching methodology.

Methods: 172 students belonging to two batches participated in the study. $79.83 \%$ of the students were satisfied with the current system. A questionnaire was prepared with 23 questions covering the current methodology, innovations, learning methods and faculty qualities.

Results: $77.70 \%$ of the students opined that the present system of medical teaching in pharmacology was satisfactory. $40 \%$ of the students thought that interactive sessions are desirable. 52.8\% students said that was that seminars can be fun once in a while with $21.35 \%$ saying that only the group leaders benefit from seminars. $60.8 \%$ said bedside teaching sessions were interesting and useful. 52.67\% students thought that problem-based learning (PBL) could be interesting and $21.5 \%$ thought it is essential.

Conclusions: The survey reveals that the students are satisfied with the current system on the whole. However they require changes in some areas like lectures and seminars. They appear willing and enthusiastic to accept new concepts in teaching. Hence, newer teaching-learning methodologies should be tried and adopted for better classroom results.
\end{abstract}

Keywords: Medical education, Pharmacology, Innovative teaching

\section{INTRODUCTION}

India has one of the largest medical education systems in the world. There have been many calls for changes in the medical education system in our country over the last few decades. Doubts are being raised about the current system of medical education, and the general opinion is that the graduate doctors that emerge from the portals of a medical school are ill-equipped with skills required to be a good medical practitioner. ${ }^{1}$

Medical education technology is constantly changing by leaps and bounds and it is essential to keep abreast of the recent techniques to keep the students focussed in the classroom, and to generate more interest in the medical study. Novel medical teaching methods have been incorporated by many medical colleges all over India with advances in technology. Lectures have given way to seminars, tutorials and group discussions. Blackboard is hardly being used by the junior faculty as they are more comfortable with the audio-visual aids. E-learning methods have been incorporated as teaching methodology innovation.

Coping with the changes is not easy, and medical colleges globally have been increasingly confronted with 
the challenge of making their curricula more meaningful and relevant, good enough to produce doctors oriented to the needs of the community. ${ }^{2}$ Students have been asking for integrated curricula and team training, but health profession educators have been slow to respond. ${ }^{3}$

Presently, new curricular elements are being developed in response to student, faculty and public initiatives. These include integration of basic and clinical sciences, emphasis on professionalism and ambulatory care, improving students' tolerance and their ability to understand their patients. ${ }^{4}$

The main objective of teaching pharmacology to undergraduate medical students so that they can take rational therapeutic decisions is not satisfactorily achieved by the present curricula being followed in the Indian scenario. ${ }^{5}$ The need for a proper linkage between curricular goals and the actual curriculum, updates in medical course, constant student assessment and feedback and innovations in medical teaching techniques is necessary.

It is also necessary to receive feedback and input from the students regarding our teaching methodologies. Our aim was to learn from the learners about their opinion regarding the current teaching methodology in pharmacology and the changes desired by them in the classroom teaching.

\section{METHODS}

A questionnaire-based study was planned for two groups of students- fourth semester and sixth semester in Goa Medical College. A questionnaire was prepared with 23 questions covering the current methodology, innovations, learning methods and faculty qualities. Different options were given for students to tick, and extra space was given to offer comments. All students of fourth semester and sixth semester participated were included in the study. They were told not to reveal their identity and given free hand to offer their suggestions and comments. The questionnaires with replies were then analysed for their content, and the results prepared.

\section{RESULTS}

97 students from $4^{\text {th }}$ semester and 75 students from $6^{\text {th }}$ semester answered the questionnaire making it a total of 172 participants.

Interestingly, a majority $77.70 \%$ of the students opined that the present system of medical teaching in Pharmacology was satisfactory (Figure 1).

The preferred tools for learning for $72 \%$ of the students were textbooks as well as lecture notes. $21.5 \%$ relied on textbooks only whereas $6.5 \%$ read only lecture notes.
$20 \%$ of the students opined that most lectures are not worth listening. More than half $(56.9 \%)$ students wanted only senior teachers to take lectures. Suggestions by students on modification of lectures are shown in Table 1.

More than half $(51.5 \%)$ of the students favoured the use of audio-visual aids along with chalk and blackboard. Most of the students $(90.38 \%)$ agreed that use of videos is useful for some topics, like explaining the mechanism of action of drugs, demonstrating clinical signs/procedures and explaining physiology of processes.

$70 \%$ students felt that the staff should be approachable to the students. $53.6 \%$ of the students would like to have readymade notes at the end of each chapter, while $52.57 \%$ thought that a question-bank at the end of each chapter would also help.

\section{Table 1: Recommended modifications for classroom} lectures.

\begin{tabular}{|c|c|c|}
\hline Modifications & $\begin{array}{l}\text { IV } \\
\text { semester } \\
(\%) \\
\text { Out of } \\
97\end{array}$ & $\begin{array}{l}\text { VI } \\
\text { semester } \\
(\%) \\
\text { Out of } 75\end{array}$ \\
\hline $\begin{array}{l}\text { 1. Readymade notes at the end } \\
\text { of each chapter }\end{array}$ & $52(53.6)$ & $47(62.7)$ \\
\hline $\begin{array}{l}\text { 2. Pre-test and post-test for } \\
\text { each chapter }\end{array}$ & $20(20.6)$ & $12(16.0)$ \\
\hline $\begin{array}{l}\text { 3. Asking questions in } \\
\text { between the lecture to make it } \\
\text { interactive }\end{array}$ & $32(32.9)$ & $18(24.0)$ \\
\hline $\begin{array}{l}\text { 4. Question bank at the end of } \\
\text { each chapter }\end{array}$ & $51(52.5)$ & $34(45.3)$ \\
\hline $\begin{array}{l}\text { 5. Asking questions for } 5 \\
\text { minutes at the end of each } \\
\text { lecture }\end{array}$ & $10(10.3)$ & $12(16.0)$ \\
\hline $\begin{array}{l}\text { 6. List of MCQs/recent } \\
\text { advances at the end of each } \\
\text { lecture }\end{array}$ & $31(31.9)$ & $26(34.7)$ \\
\hline $\begin{array}{l}\text { 7. Asking questions from } \\
\text { previous lecture for a few } \\
\text { minutes before the start }\end{array}$ & $39(40.2)$ & $27(36.0)$ \\
\hline
\end{tabular}

$40 \%$ of the students thought that interactive sessions are desirable. Almost all the students (98\%) felt that humour should be used in lectures at times as it removes the monotonous narration of lecture (75\%), and also improves student-teacher relationship (68\%).

There was mixed response regarding the use of tutorials $31.26 \%$ strongly in favour, $16.30 \%$ strongly against it and $52.44 \%$ of the opinion that tutorials may be used for a few topics only. The opinion regarding seminars is shown in figure $2.52 .8 \%$ students said that seminars can be fun once in a while with $21.35 \%$ voicing their concern that only the group leaders benefit from seminars. 


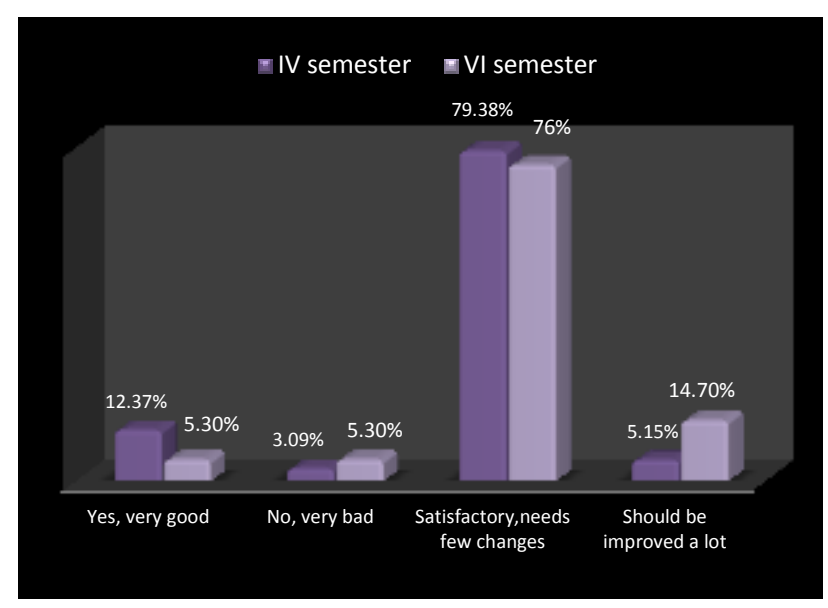

Figure 1: Student's views on present teaching system.

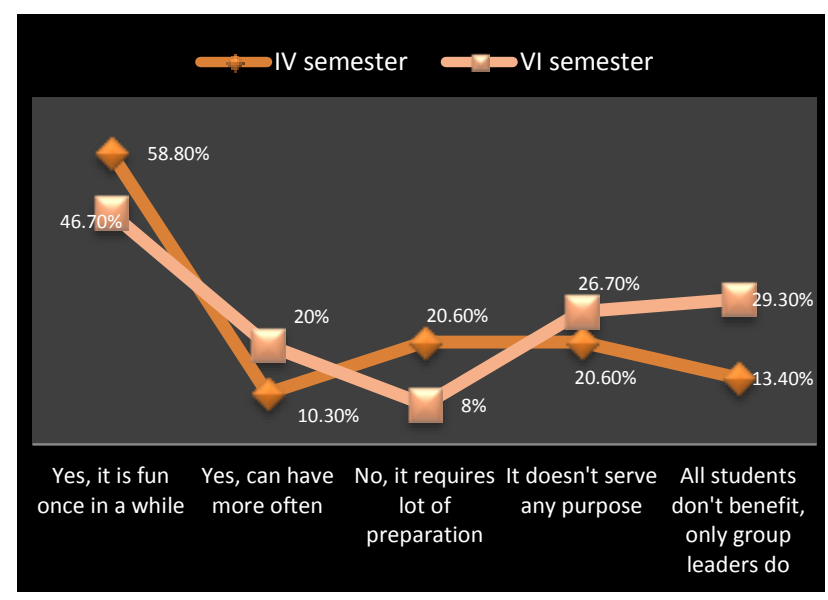

Figure 2: Student's views on seminars.

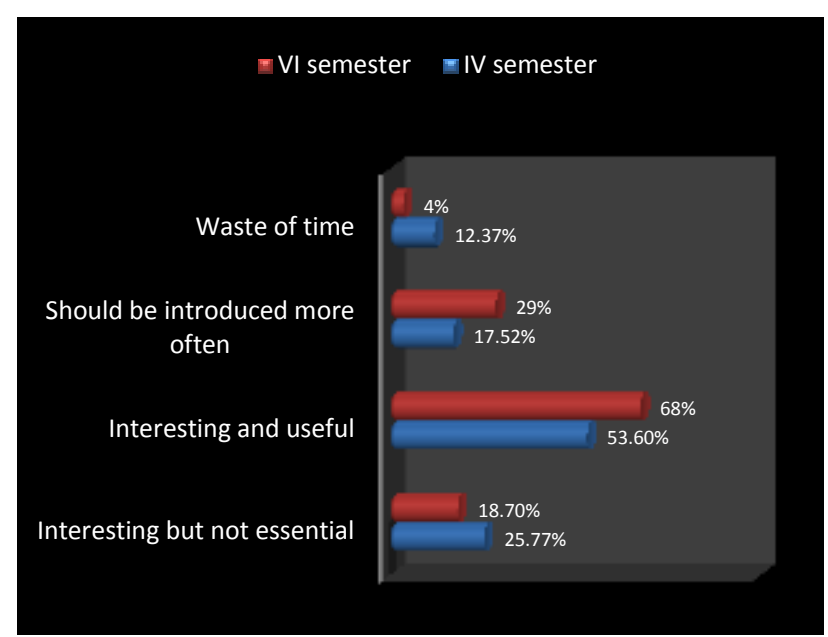

Figure 3: Student's views on bedside discussions.

Regarding bedside teaching, $60.8 \%$ said they were interesting and useful (Figure 3).

More than half $(52.67 \%)$ students thought that problembased learning (PBL) could be interesting and 21.5\% thought it is essential (Figure 4).
When asked about their opinion of the teaching faculty, only $10.3 \%$ thought that the medical faculty members live up to their expectations of a good medical teacher.

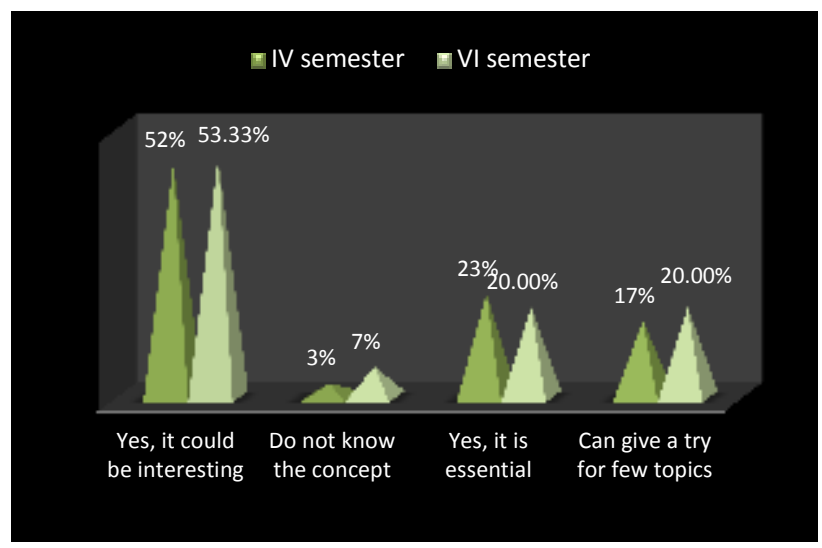

Figure 4: Student's views on problem-based learning.

\section{DISCUSSION}

The survey reveals that the students are satisfied with the current teaching methodology in pharmacology. This is in contrast with other studies from India and abroad..$^{7-9}$ Both the student groups have shown interest in newer methods like PBL, bedside teaching and seminars instead of the routine lectures only.

Most of the students $(56.9 \%)$ had faith only in senior teachers. It is often seen that inexperienced junior faculty is given the burden of medical teaching, whilst the senior faculty does nothing more than the administrative work. Students have also highlighted knowledge and skill as the two most important qualities of a good medical teacher. In 1986, Bajaj committee rightly noted that although medical faculty were effective in their clinical specialities, they were deficient as educators. ${ }^{10}$

Students are no longer interested in just attending the monotonous lectures. A lot of students have commented that the attendance should not be made compulsory. They have opined that if given an option they will only attend the lectures of their choice, when they feel that the faculty is expected to do justice to the topic. They have shown more interest in interactive sessions although they agree that lectures are an essential part of medical education and they make you understand textbooks better. Faculty should therefore take more interest in making the lectures more practical and interesting, interspersed with dose of humour (as suggested by most of the students) so that more interest is generated, and the medical students attend them with a will to learn. Our study reveals that students wouldn't mind being asked a few questions in between a lecture to make it more interactive.

Innovations in teaching are usually accepted with mixed feelings and interest. In our study, both the batches of students have shown interest in new methodologies of teaching like student seminars, PBL and bedside 
teaching. They have shown more inclination towards use of videos in classrooms to explain the physiological processes, surgical procedures, clinical signs or mechanism of action of drugs. Newer methodologies can be implemented only if the faculty shows interest and determination to introduce something new. Lack of incentives to the teachers is one reason why the medical teachers nationwide are reluctant to come forward and do something new for the students. ${ }^{1}$

In our study, a majority of the students thought that PBL could be interesting. PBL is a form of curriculum often promoted by student Learning theorists ${ }^{11,12}$ and involves a deep approach to a subject that is learnt. In a university in Slovakia, a hybrid of PBL and lectures was used to teach medical pharmacology, which improved the decisionmaking skills of the students. ${ }^{13}$ More and more colleges should try to incorporate PBL in their curriculum, as it has been proved to stimulate a deep learning process. ${ }^{14}$ The problems are used as a focus for the study of basic science and clinical applications integrated with the knowledge of clinical reasoning skills. ${ }^{15}$ Such a method is more effective than the traditional approach. ${ }^{16}$

Student seminars are another effective method of selfdirected or learner-centred learning. In our study, $52.8 \%$ students supported student seminars as a good group activity when used judiciously, although many opined that it is more beneficial to few rather than all in a group. For effective participation, all the students in a group can be given a task to perform so that nobody feels 'kept out'. Tutorials also have a similar utility, where students are divided into groups for discussing a topic decided before. Many students feel they can be useful for some topics. Problem solving interactive clinical seminars for undergraduates can make the learning process more effective. $^{17}$

Bedside teaching can be a good mode of multidisciplinary approach where the clinical/applied aspects of a case are discussed pertaining to the topic provided in basic/paramedical sciences like pharmacology or microbiology. Our study has revealed that many students feel this situational bedside approach to be interesting and useful. Other studies have published similar findings.

\section{CONCLUSION}

Our study reveals that the students will welcome a change if incorporated in the current medical educational system. Although they do not entirely agree that the current medical education system is good, they are sure that it is not bad either. They would appreciate innovative methods in learning medicine and expect more involvement from the faculty to make classes interesting.

\section{ACKNOWLEDGEMENTS}

We thank the MBBS students of the fourth and sixth semester of Goa Medical College for participating in our study and sharing their valuable comments.

\author{
Funding: No funding sources \\ Conflict of interest: None declared \\ Ethical approval: Not required
}

\section{REFERENCES}

1. Goudar SS, Kotur PF. Trends in medical education. Indian J. Anaesth. 2003;47(1): 25-9.

2. Majumder AA, D'souza U, Rahman S. Trends in medical education: challenges and directions for need-based reforms of medical training in south-east Asia. Indian J Med Sci. 2004;58(9):369-80.

3. Skochelak SE. A century of progress in medical education: what about the next 10 years? Acad Med. 2010;85(2):197-200.

4. Clever LH. Some things have not changed. Ann Intern Med. 2000;132:85-9.

5. Desai M. Changing face of pharmacology practicals for medical undergraduates. Indian J Pharmacol. 2009;41:151-2.

6. Kacker SK, Adkoli BV. Need-based undergraduate medical curriculum. Indian J Pediatr. 1993,60:751-7.

7. Akat PB, Karande VB, Murthy MB, Burute SR. Interns opinion on 'bedside pharmacology clinics' and its incorporation in undergraduate curriculum. $\mathbf{J}$ Pharmacol Pharmacother. 2012;3(1):56-8.

8. Badyal DK, Bala S, Kathuria P. Student evaluation of teaching and assessment methods in pharmacyology. Indian J Pharmacol 2010;42:87-9.

9. The attitude of medical students of tabriz university of medical sciences towards the necessity of clinical pharmacology. Future of Medi Edu J. 2012;2(1):325.

10. National Institute of Health and Family Welfare. National Health Committees, Bajaj Committee recommendations. New Delhi: National Document Center. Available at: http://www.nihfw.org/NDC/DocumentationServices/ Committe_and_commission.html.

11. Evensen DH, Hmelo CE. Problem-based learning: a research perspective on learning interactions. Mawah, NJ: Lawrence Earlbaum Associates,;2000: vii-ix.

12. Naidu S. Learning design as an indicator of quality in teacher education. Paper presented at NAAC COL roundtable on innovations in teacher education, Bangalore, India, 2004.

13. Tisonova J, Hudec R, Szalayova A, Bozekova L, Wawruch M, Lassanova M, Vojtko R, Jezova D, Kristova V, Kriska M. Experience with problem oriented teaching in pharmacology. Bratisl Lek Listy. 2005; 106:83-7. 
14. Dolmans DHJM, Wolfhagen IHAP, Ginns P. Measuring approaches to learning in a problem based learning context. International $\mathrm{J}$ Med Edu. 2010;1:55-60.

15. Barrows HS, Tamblyn RN. Problem based learning: an approach to medical education. New York : Springer publishing company; 1980.

16. Pallie W, Carr DH. The McMaster medical education philosophy in theory, practice and historical perspective. Med Teacher. 1987;9:59-71.
17. Rao BB, Kate V. Problem solving interactive clinical seminars for undergraduates. J Pharmacol Pharmacother. 2012;3:205-6.

Cite this article as: Misal DD, Maulingkar SV, D’Mello MA, Rataboli PV. Students' opinions on the prevailing and innovative methods in medical education technology and changes recommended. Int J Basic Clin Pharmacol 2016;5:121-5. 